\title{
A steady-state analysis of the temperature responses of water vapor and aerosol lifetimes
}

\author{
G.-J. Roelofs \\ Institute for Marine and Atmospheric Research Utrecht (IMAU), Utrecht University, the Netherlands \\ Correspondence to: G.-J. Roelofs (g.j.h.roelofs@uu.nl)
}

Received: 4 June 2012 - Published in Atmos. Chem. Phys. Discuss.: 4 July 2012

Revised: 25 June 2013 - Accepted: 5 July 2013 - Published: 21 August 2013

\begin{abstract}
The dominant removal mechanism of soluble aerosol is wet deposition. The atmospheric lifetime of aerosol, relevant for aerosol radiative forcing, is therefore coupled to the atmospheric cycling time of water vapor. This study investigates the coupling between water vapor and aerosol lifetimes in a well-mixed atmosphere. Based on a steady-state study by Pruppacher and Jaenicke (1995) we describe the coupling in terms of the processing efficiency of air by clouds and the efficiencies of water vapor condensation, of aerosol activation, and of the transfer from cloud water to precipitation. We extend this to expressions for the temperature responses of the water vapor and aerosol lifetimes. Previous climate model results (Held and Soden, 2006) suggest a water vapor lifetime temperature response of $+5.3 \pm 2.0 \% \mathrm{~K}^{-1}$. This can be used as a first guess for the aerosol lifetime temperature response, but temperature sensitivities of the aerosol lifetime simulated in recent aerosolclimate model studies extend beyond this range and include negative values. This indicates that other influences probably have a larger impact on the computed aerosol lifetime than its temperature response, more specifically changes in the spatial distributions of aerosol (precursor) emissions and precipitation patterns, and changes in the activation efficiency of aerosol. These are not quantitatively evaluated in this study but we present suggestions for model experiments that may help to understand and quantify the different factors that determine the aerosol atmospheric lifetime.
\end{abstract}

\section{Introduction}

Aerosol influences the radiative budget through scattering and absorption of solar radiation (the direct and semi-direct effects) and their influence on cloud reflective properties (the first indirect effect) (Twomey, 1974; Forster et al., 2007; Lohmann and Feichter, 2005) and precipitation formation (the second indirect effect) (Albrecht, 1989; Rosenfeld et al., 2008). Estimated direct and indirect forcings together range between -0.6 and $-2.4 \mathrm{~W} \mathrm{~m}^{-2}$ (Forster et al., 2007) and this uncertainty has not been reduced much in the last decades (Lohmann et al., 2010). The combination of the relatively large uncertainties in aerosol forcing as well as in simulated climate sensitivity (between 2.1 to $4.4^{\circ} \mathrm{C}$, Solomon et al., 2007) provides sufficient leeway for individual climate models to simulate a surface temperature increase over the past $150 \mathrm{yr}$ that is consistent with observations, but it hampers accurate prediction of future climate change (Andreae et al., 2005; Knutti and Hegerl, 2008). Models display a significant correlation between climate sensitivity and anthropogenic aerosol forcing (Kiehl, 2007; Kerr, 2007).

The uncertainty in the estimated anthropogenic aerosol forcing reflects the complex ways in which aerosol physical and chemical properties determine the radiative forcing. Topics addressed in recent studies are, for example, the quantification of emissions of aerosol and aerosol precursors (e.g., Dentener et al., 2006), the secondary formation of organic and inorganic aerosol in the atmosphere (e.g., Jacobson et al., 2000; Jimenez et al., 2009), the capability of aerosol to act as cloud condensation nuclei and their influence on precipitation formation (e.g., Dusek et al., 2006; Rosenfeld et al., 2008), and the influence of the volatility of (in)organic species on cloud formation (e.g., Donahue et al., 2011; Topping and McFiggans, 2012).

Current uncertainties lead to relatively large intermodel differences in aerosol representation. In the first place, different representations of aerosol (precursor) emissions, aerosol 
physical and chemical processes, and aerosol removal lead to differences in simulated aerosol burdens and lifetimes. Wet deposition of aerosol, which is subject of this study, is an important removal process for soluble inorganic aerosol species such as sulfate and nitrate, which have a strong anthropogenic signature (Charlson et al., 1992; Dentener et al., 2006). For example, Croft et al. (2010) calculate that $53 \%$ and $43 \%$ of global sulfate are removed by stratiform and convective precipitation, respectively, while $4 \%$ is removed by dry deposition. Accurate simulation of aerosol wet deposition is necessary for an accurate representation of longrange aerosol transport (e.g., Shindell et al., 2008). Global aerosol models display a large range of computed sulfate lifetimes and wet deposition efficiencies, and a strong negative correlation between both. For example, in the atmospheric (bulk) sulfur model intercomparison study COSAM (Comparison of large-scale sulfur models; 1999), simulated wet deposition efficiencies for Europe range between 0.1 and $0.5 \mathrm{day}^{-1}$, and they are associated with sulfate lifetimes between 6 and 1 days, respectively (Roelofs et al., 2001). A more recent intercomparison study with relatively sophisticated aerosol models, carried out in the framework of the aerosol intercomparison initiative AeroCom, reported a similar behavior with global wet removal efficiencies between 0.15 and 0.3 day $^{-1}$ for sulfate and global sulfate lifetimes between 3 and 0.5 days (Textor et al., 2006; their Figs. 5d and 4a). In the second place, so-called "host-model" uncertainties cause part of the variability. An AeroCom intercomparison study in which optical properties of aerosol were prescribed instead of their concentrations (Stier et al., 2013) showed a relative standard deviation of the order of $10 \%$ of computed radiative forcings between models. The variability was attributed to the radiative transfer schemes implemented in the models and to the simulated surface albedo and spatial and temporal distribution of clouds.

In the third place, uncertainties may reflect intermodel differences in the simulated temperature sensitivity of the hydrological cycle. A warming climate causes increasing evaporation of water, and this induces a larger atmospheric water vapor burden and more precipitation. For model experiments with doubled carbon dioxide concentrations, computed temperature sensitivities of the water vapor burden and precipitation amount, averaged over a series of climate models, are $7.5 \% \mathrm{~K}^{-1}$ and $2.2 \% \mathrm{~K}^{-1}$, respectively (Held and Soden, 2006). The actual magnitude of simulated temperature sensitivities depends on the nature of the forcing, i.e., shortwave or longwave, which determines the so-called fast response with adjustment of radiative and non-radiative (latent and sensible heat) fluxes (e.g., Allen and Ingram, 2002; Lambert and Faull, 2007; Bala et al., 2008; Bala et al., 2009). Also, computed precipitation temperature sensitivities are smaller for transient than for equilibrium climate model simulations (Andrews and Forster, 2010).

The difference between the water vapor and precipitation temperature sensitivities implies a larger atmospheric life- time of water vapor in a warmer climate, which can be attributed to changes in simulated cloudiness and precipitation formation. The radiative consequences of these changes are expressed in the so-called cloud radiative feedback and contribute relatively much to the intermodel variability in climate sensitivity (Dufresne and Bony, 2008; Andrews et al., 2012; Webb et al., 2013). However, these changes may also affect the efficiency of aerosol wet deposition. A recent climate model study (Fang et al., 2011) indicated that the atmospheric lifetime of an ideal aerosol-like tracer changes between different climates, mainly due to shifting cloud and precipitation patterns and a decreased precipitation frequency. We note that this climate-change-induced modification of the aerosol lifetime influences the atmospheric burden and thus induces an aerosol radiative forcing even when other properties (emissions, size distribution, chemical composition) remain the same.

The direct coupling between the hydrological cycle and the lifetime of aerosol thus may lead to different radiative forcings by natural aerosol in the pre-industrial and presentday climates. However, it is still a relatively unexamined aspect in the context of climate change and aerosol forcing. This study investigates the coupling between the aerosol atmospheric lifetime and cloud and precipitation characteristics and its sensitivity to a surface temperature change by expressing the relation between the atmospheric lifetimes of water vapor and aerosol in terms of basic cloud and precipitation parameters. We consider a well-mixed moist atmosphere that contains an ideal bulk aerosol for which wet deposition is the only removal mechanism. The study is based on Pruppacher and Jaenicke (1995), who use a steady-state approach to express the atmospheric lifetimes of water vapor and aerosol in terms of the processing efficiency of air by (precipitating) clouds and by the aerosol activation or scavenging efficiency. Section 2 commences with similar basic expressions for both lifetimes and continues with expressions for their temperature sensitivities. A first estimate of the magnitude of the aerosol lifetime temperature response is derived from reported climate model results. In Sect. 3 this estimate is compared with computed aerosol lifetimes from several aerosol-climate model studies. The comparison suggests that other factors than the simulated aerosol lifetime temperature response have a larger impact on aerosol lifetime. These factors are not quantified further in this study, but we suggest model experiments to analyze and compare the relation between the water vapor and aerosol atmospheric cycles in climate models. Section 4 presents a summary and discussion.

\section{Water vapor and aerosol lifetimes}

\subsection{First-order removal}

The domain under study is the troposphere, where most water vapor and aerosol reside. Figure 1 illustrates that water vapor 
and aerosol originate from different sources while they are removed by the same precipitation events, and lists the relevant parameters considered in this study. First we derive an expression for the water vapor lifetime, $\tau_{\mathrm{v}}(\mathrm{s})$. The water vapor cycle is assumed to be in steady state so that $w_{\mathrm{v}}=E / L_{\mathrm{V}}$, with $w_{\mathrm{v}}$ the concentration of water vapor (e.g., $\mathrm{g} \mathrm{m}^{-3}$ ), $E$ the evaporation flux $\left(\mathrm{g} \mathrm{m}^{-3} \mathrm{~s}^{-1}\right)$, and $L_{\mathrm{v}}$ the first-order removal rate of water vapor $\left(\mathrm{s}^{-1}\right)$. We note that atmospheric water besides water vapor also refers to liquid and ice clouds. Our approach reflects that cloud water and ice that does not precipitate is returned to the atmosphere as water vapor. In a well-mixed tropospheric column of altitude $H(\mathrm{~m})$ and unit surface area the fraction of air, $F_{\text {air }}\left(\mathrm{s}^{-1}\right)$, passing through all clouds is

$F_{\text {air }}=\left(\sum_{i} c_{i} U_{i} / H\right)$,

with $c_{i}$ and $U_{i}$ the average fractional cloud cover and updraft velocity for cloud type $i$, respectively. Introducing $e_{\mathrm{c}, i}$ for the condensation efficiency in cloud type $i$, i.e., the ratio of the cloud water mass and the mass of water vapor entering the cloud, the rate $\left(\mathrm{g} \mathrm{m}^{-3} \mathrm{~s}^{-1}\right)$ at which water vapor condenses becomes

$F_{\mathrm{air}, \mathrm{c}}=\left(\sum_{i} e_{\mathrm{c}, i} c_{i} U_{i} / H\right) w_{\mathrm{v}}$.

If $p_{\mathrm{c}, i}$ is the fraction of the cloud water transferred to precipitation, the precipitation flux $F_{\text {air,p }}\left(\mathrm{g} \mathrm{m}^{-3} \mathrm{~s}^{-1}\right)$ is

$F_{\mathrm{air}, \mathrm{p}}=\left(\sum_{i} e_{\mathrm{c}, i} p_{\mathrm{c}, i} c_{i} U_{i} / H\right) w_{\mathrm{v}}$.

The first-order removal rate $L_{\mathrm{v}}$ and lifetime $\tau_{\mathrm{v}}$ for water vapor then become

$L_{\mathrm{v}}=1 / \tau_{\mathrm{v}}=\left(\sum_{i} e_{\mathrm{c}, i} p_{\mathrm{c}, i} c_{i} U_{i} / H\right)$.

We remark that Pruppacher and Jaenicke (1995) take the same value for $e_{c}(0.3)$ for all cloud types, and that they use the average fraction of the clouds that actually precipitate (1/11) instead of $p_{c}$. They estimate a water vapor lifetime in the atmosphere of $\sim 9$ days. Our Eq. (4) reflects that $e_{\mathrm{c}}$ and $p_{\mathrm{c}}$ may vary between different clouds and therefore provides a more realistic description of clouds in the atmosphere and in climate models.

A similar equation is developed for aerosol. Aerosol often consists of different chemical components that enter the atmosphere after primary or secondary production and are removed through dry or wet deposition. The steady-state concentration $w_{\mathrm{AP}}\left(\mathrm{g} \mathrm{m}^{-3}\right)$ of an aerosol species $j$ is then given by

$w_{\mathrm{AP}, j}=\left(S_{\mathrm{prim}, j}+S_{\mathrm{sec}, j}\right) /\left(L_{\mathrm{dry}, j}+L_{\mathrm{wet}, j}\right)$,

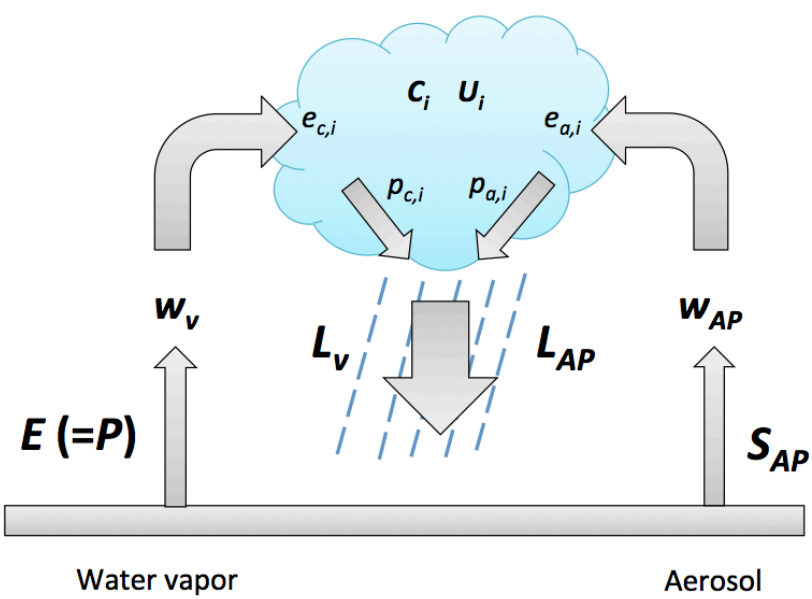

Fig. 1. Atmospheric cycles of water vapor and soluble aerosol. The symbols are explained in Sect. 2.1.

where $S$ is the source strength $\left(\mathrm{g} \mathrm{m}^{-3} \mathrm{~s}^{-1}\right)$ following primary (prim) and secondary (sec) production, and $L_{\mathrm{dry}}$ and $L_{\mathrm{wet}}$ refer to dry and wet aerosol removal efficiencies $\left(\mathrm{s}^{-1}\right)$. The significance of each term in Eq. (5) depends on the chemical species. For example, desert dust is associated with primary production and is predominantly removed by dry deposition, while sulfate and organic matter, both of which strongly contribute to the anthropogenic aerosol radiative forcing (Forster et al., 2007), are predominantly secondarily formed and removed by wet deposition (e.g., Roelofs et al., 1998; Stier et al., 2005, Croft et al., 2010). For an ideal aerosol species for which wet deposition is the only or dominant removal mechanism the steady-state equation is $w_{\mathrm{AP}}=S_{\mathrm{AP}} / L_{\mathrm{AP}}$, where $L_{\mathrm{AP}}$ represents the first-order loss rate due to wet deposition. Based on the total air flux into clouds (Eq. 1), the rate $\left(\mathrm{g} \mathrm{m}^{-3} \mathrm{~s}^{-1}\right)$ at which aerosol is taken up by the cloud water and subsequently removed by precipitation is expressed as

$F_{\text {air,dep }}=\left(\sum_{i} e_{\mathrm{a}, i} p_{\mathrm{a}, i} c_{i} U_{i} / H\right) w_{\mathrm{AP}}$.

The term $e_{\mathrm{a}, i}$ is the activation efficiency, i.e., the fraction of aerosol taken up in the aqueous phase during cloud formation, for each cloud type $i$. The efficiency depends on physical and chemical characteristics of the aerosol that determine the critical supersaturation of individual particles, and on cloud dynamics, i.e., $e_{\mathrm{a}}$ is generally larger in convective than in stratiform clouds (e.g., Jensen and Charlson, 1984). The term $p_{\mathrm{a}}$ is the fraction of aerosol in the cloud water that is transferred to precipitation, in a similar way as $p_{\mathrm{c}}$ for water vapor. For a bulk approach, i.e., the dissolved aerosol matter is homogeneously distributed over the cloud drop sizes, $p_{\mathrm{a}}$ and $p_{\mathrm{c}}$ have the same value, but they differ when concentration differences between drop sizes are taken into account. Pruppacher and Jaenicke (1995) used arbitrary values for $e_{\mathrm{a}}$ 
of 0.5 and 1.0, independent of cloud type, while for $p_{\mathrm{a}}$ the precipitating cloud fraction $(1 / 11)$ was used.

The aerosol removal rate $L_{\mathrm{AP}}$ and lifetime $\tau_{\mathrm{AP}}$ are

$L_{\mathrm{AP}}=1 / \tau_{\mathrm{AP}}=\left(\sum_{i} e_{\mathrm{a}, i} p_{\mathrm{a}, i} c_{i} U_{i} / H\right)$.

The close coupling between aerosol and water vapor lifetimes follows from

$\frac{\tau_{\mathrm{AP}}}{\tau_{\mathrm{v}}}=\frac{\sum_{i} e_{\mathrm{c}, i} p_{\mathrm{c}, i} c_{i} U_{i}}{\sum_{i} e_{\mathrm{a}, i} p_{\mathrm{a}, i} c_{i} U_{i}}$.

Equation (8) demonstrates the dependence of both lifetimes on the processing efficiency of air by clouds (Eq. 1), expressed through $c$ and $U$. The magnitude of the ratio of both lifetimes depends on the efficiencies of water vapor condensation, aerosol activation and the transfer from cloud to precipitation water. Equation (8) can be used as a basis for a model intercomparison of water vapor and aerosol lifetimes, presented in Sect. 3.

\subsection{Temperature sensitivities}

The sensitivity of the water vapor concentration to a change in surface temperature is directly derived from the steadystate equation $w_{\mathrm{v}}=E / L_{\mathrm{v}}$ (for longer time scales (months, year) the source of water vapor, i.e., evaporation $E$, can be represented by precipitation $P$ ) and Eq. (4):

$\frac{\mathrm{d} \ln w_{\mathrm{v}}}{d \Delta T}=\frac{\mathrm{d} \ln P}{d \Delta T}-\frac{\mathrm{d} \ln \left(\sum_{i} e_{\mathrm{c}, i} p_{\mathrm{c}, i} c_{i} U_{i} / H\right)}{\mathrm{d} \Delta T}$.

The second term on the right-hand side describes the temperature sensitivity of aerosol removal, in terms of the efficiency of air being processed by clouds, through $c$ and $U$, and the condensation and precipitation formation efficiency for water through $e_{\mathrm{c}}$ and $p_{\mathrm{c}}$. A first estimate of this term can be derived from Held and Soden (2006), who present simulated temperature sensitivities for water vapor and precipitation in response to a longwave (LW) forcing for several climate models. With uncertainty ranges estimated from their Fig. 2, the temperature sensitivity of the atmospheric water vapor concentration is $7.5 \pm 1.5 \% \mathrm{~K}^{-1}$ and that of the precipitation flux is $2.2 \pm 1.1 \% \mathrm{~K}^{-1}$. The latter is in good agreement with the analysis of Andrews and Forster (2010). The second term on the right-hand side of Eq. (9) then becomes $-5.3 \% \mathrm{~K}^{-1}$, with an estimated uncertainty of $2.0 \% \mathrm{~K}^{-1}$. Consequently, the response of the water vapor lifetime to a surface temperature change, which is expressed by

$\frac{\mathrm{d} \ln \tau_{\mathrm{v}}}{\mathrm{d} \Delta T}=-\frac{\mathrm{d} \ln \left(\sum_{i} e_{\mathrm{c}, i} p_{\mathrm{c}, i} c_{i} U_{i} / H\right)}{\mathrm{d} \Delta T}$, becomes $+5.3 \pm 2.0 \% \mathrm{~K}^{-1}$, i.e., the water vapor lifetime increases with temperature. This will be further referred to as the water vapor lifetime temperature response, or WLTR. We note that the nature of the forcing, i.e., shortwave or longwave, has a significant influence. For example, Bala et al. (2008) simulate a precipitation temperature sensitivity of $1.5 \% \mathrm{~K}^{-1}$ for a $\mathrm{LW}$ forcing and $2.4 \% \mathrm{~K}^{-1}$ for a shortwave (SW) forcing, while simulated sensitivities of the water vapor concentration are approximately the same, i.e., about $6.3 \% \mathrm{~K}^{-1}$. This implies that the WLTR may be smaller for a SW than for a LW forcing.

In a similar fashion the temperature dependence of the aerosol concentration is expressed as

$\frac{\mathrm{d} \ln w_{\mathrm{AP}}}{\mathrm{d} \Delta T}=\frac{\mathrm{d} \ln S_{\mathrm{AP}}}{\mathrm{d} \Delta T}-\frac{\mathrm{d} \ln \left(\sum_{i} e_{\mathrm{a}, i} p_{\mathrm{a}, i} c_{i} U_{i} / H\right)}{\mathrm{d} \Delta T}$

or as a function of time:

$\frac{\mathrm{d} \ln w_{\mathrm{AP}}}{\mathrm{d} t}=\frac{\mathrm{d} \ln S_{\mathrm{AP}}}{\mathrm{d} t}-\frac{\mathrm{d} \ln \left(\sum_{i} e_{\mathrm{a}, i} p_{\mathrm{a}, i} c_{i} U_{i} / H\right)}{\mathrm{d} \Delta T} \frac{\mathrm{d} \Delta T}{\mathrm{~d} t}$,

where $\mathrm{d} \Delta T / \mathrm{d} t$ reflects the rate of temperature change. The first term on the right-hand side of Eq. (12) describes changing aerosol emissions; these may be associated with anthropogenic activities but also with temperature-dependent processes such as climate-biosphere feedbacks and chemical transformation rates (Carslaw et al., 2010). The last term refers to a change in the processing of the atmosphere by clouds as discussed above, and in the aerosol activation efficiency and the fraction of the dissolved aerosol mass that is transferred to precipitation. The temperature response of the aerosol lifetime (further referred to as ALTR) is given by

$\frac{\mathrm{d} \ln \tau_{\mathrm{AP}}}{\mathrm{d} \Delta T}=-\frac{\mathrm{d} \ln \left(\sum_{i} e_{\mathrm{a}, i} p_{\mathrm{a}, i} c_{i} U_{i} / H\right)}{\mathrm{d} \Delta T}$.

The ALTR is a potentially significant factor for the aerosol radiative forcing even when other aerosol characteristics such as size distribution and chemical composition remain the same.

A first guess of the magnitude of ALTR can be obtained by assuming for simplicity that $e_{\mathrm{c}}, e_{\mathrm{a}}, p_{\mathrm{c}}$ and $p_{\mathrm{a}}$ do not change significantly upon temperature change, so that the lifetime is affected only through changes in cloud cover and updraft velocity. In that case, ALTR and WLTR are of equal magnitude, i.e., $5.3 \pm 2.0 \% \mathrm{~K}^{-1}$. Examination of the Clausius Clapeyron equation indicates that the temperature sensitivity of the condensation efficiency $e_{\mathrm{c}}$ is generally smaller than $0.5 \% \mathrm{~K}^{-1}$, and its influence on the water vapor lifetime change is likely relatively small. However, the aerosol activation efficiency $e_{\mathrm{a}}$ may have changed significantly during the last $150 \mathrm{yr}$ but it is uncertain by how much in view of the complexity and compensating effects involved. Changes may be related to a temperature change. For example, the amount of semi-volatile 
matter condensed in the aerosol phase decreases with increasing temperature (Topping and McFiggans, 2012) and this implies a reduction of $e_{\mathrm{a}}$. Further, aerosol scavenging efficiencies are generally smaller in polluted air than in the cleaner pre-industrial air (e.g., Jensen and Charlson, 1984). Finally, processing of less soluble aerosol in polluted air leads to more hygroscopic aerosol (Stier et al., 2006) and thus implies a larger $e_{\mathrm{a}}$.

\section{Aerosol lifetimes in aerosol-climate models}

\subsection{Comparison of temperature sensitivities}

In contrast with our approach in Sect. 2, three-dimensional aerosol climate models are relatively complex: they display large temporal and spatial variabilities in water vapor and aerosol concentrations, they consider mechanisms for secondary aerosol formation and aerosol is removed from the atmosphere in various ways. It can be expected that many parameters other than the temperature sensitivity of clouds and precipitation contribute to a change in aerosol lifetime. We compare the estimated ALTR of $5.3 \% \mathrm{~K}^{-1}$ with the results of four global modeling studies that report computed temperature sensitivities for precipitation and global (sulfate) aerosol lifetimes, which are listed in Table 1. The studies apply a LW or SW forcing, or a mixture of both. Simulated temperature sensitivities for precipitation range between 2.0 and $2.8 \% \mathrm{~K}^{-1}$, consistent with Held and Soden (2006). The studies do not explicitly report computed sensitivities of the atmospheric water vapor concentration, except for Racherla and Adams (2006), who simulate a temperature sensitivity of $8.2 \% \mathrm{~K}^{-1}$. The other climate models are included in the analysis by Held and Soden (2006), who find a consistent temperature sensitivity of the water vapor concentration of approximately $7.5 \% \mathrm{~K}^{-1}$ for all models. It can be noticed that the modeled values of ALTR listed in the right column in Table 1 are generally smaller than the derived $5.3 \% \mathrm{~K}^{-1}$ and also include negative values.

The GFDL study (Fang et al., 2011) considers ideal soluble tracers and an aerosol removal efficiency that depends on the ratio of precipitation rate and precipitable water. Ideal tracer emissions are located mostly in (sub)tropical regions, concurring with the strongest evaporation fluxes. That study is therefore to some extent comparable to our approach and the computed ALTR is in relatively good agreement with our derived value. Fang et al. (2011) attribute the lifetime increase to a decrease in large-scale precipitation over land and a decreased precipitation frequency.

Comparison is less straightforward for the other model studies that consider size-resolved aerosol and more realistic aerosol dynamics, microphysics and emission distributions for several aerosol species. From the study with ECHAMHAM (Kloster et al., 2010) we consider two scenarios: one with changes in greenhouse gas (GHG) emissions only and
Table 1. Simulated temperature sensitivities of precipitation and sulfate lifetime.

\begin{tabular}{lllll}
\hline & Model & $\begin{array}{l}\Delta F \\
\left(\mathrm{~W} \mathrm{~m}^{-2}\right)\end{array}$ & $\begin{array}{l}\Delta P / \Delta T \\
(\% / \mathrm{K})\end{array}$ & $\begin{array}{l}\Delta \tau_{\mathrm{AP}} / \Delta T \\
(\% / \mathrm{K})\end{array}$ \\
\hline This study $^{\mathrm{a}}$ & & LW & $2.2 \pm 1.1$ & $5.3 \pm 2.8$ \\
Fang et al. (2011) $^{\mathrm{b}}$ & GFDL & LW & +2.2 & +6.1 \\
Kloster et al. (2010) $^{\mathrm{c}}$ & ECHAM & LW & +2.0 & +2.4 \\
Kloster et al. (2010) $^{\mathrm{d}}$ & ECHAM & LW, SW & +2.4 & +3.9 \\
Liao et al. (2006) $^{\mathrm{e}}$ & GISS-II & LW & +2.0 & -3.1 \\
Racherla/Adams (2006) $^{\mathrm{f}}$ & GISS-II & SW & +2.8 & -6.2 \\
\hline
\end{tabular}

a Based on Held and Soden (2006).

b Ideal soluble tracer, long-lived greenhouse gas concentrations yr 1990 vs. 2090.

c Emission changes for greenhouse gases, yr 2000 vs. 2030.

${ }^{\mathrm{d}}$ Emission changes for greenhouse gases and aerosol, yr 2000 vs. 2030.

e $\mathrm{CO}_{2}$ increase from 368 to $836 \mathrm{ppb}$, unchanged emissions, yr 2000 vs. 2100 .

${ }^{\mathrm{f}}$ Forcing of surface temperature from changes in ocean boundary conditions, unchanged emissions, yr 1990 vs. 2050.

the other with changes in both GHG and aerosol (precursor) emissions. Different precipitation temperature sensitivities are computed, consistent with the different responses to LW and SW forcings as described in section 2.2. The computed temperature sensitivities of the sulfate lifetime are positive but smaller than our estimate. The two studies with GISS (Racherla and Adams, 2006; Liao et al., 2006) also use a detailed aerosol scheme but simulate negative values for the aerosol lifetime change. This is attributed by the authors to the increased precipitation, but also to differences in the simulated seasonalities of precipitation and aerosol concentrations. A study with HadGEM2-ES (Bellouin et al., 2011; not listed in Table 1) computes a sulfate lifetime that varies from 3.8 days in 1850 to 3 days in 1960 and then to 4 days at the end of the 21 st century. The simulated decrease of the sulfate lifetime between 1850 and 1960 is due to the fact that anthropogenic activities caused a relocation of the main sulfur dioxide emissions from the (sub-)tropics to extratropical regions, thus situating them closer to the northern hemispheric storm tracks where precipitation is abundant. The subsequent increase reflects that anthropogenic aerosol (precursor) emissions decrease again in these regions.

\subsection{Proposed analysis of simulated water vapor and aerosol lifetimes}

A better understanding of aerosol radiative forcing requires a quantitative insight in the intermodel variability in computed aerosol burden. Section 2 showed that the wet removal rate of aerosol is directly linked to that of water vapor through cloud cover $c$ and updraft velocity $U$, while Sect. 3.1 showed that the aerosol lifetime is also influenced by the simulated transport between locations where aerosol is emitted (or secondarily produced) and where it is removed by precipitating clouds. In addition, the activation efficiency $e_{\mathrm{a}}$ is important for aerosol removal. It depends non-linearly on aerosol physical and chemical properties and on cloud formation dynamics. Global aerosol models use approaches of different 
complexity to compute aerosol uptake in clouds during cloud formation, such as prescribed scavenging efficiencies for each cloud type (e.g., Stier et al., 2005), parameterizations derived from cloud parcel model simulations (e.g., Roelofs et al., 2006) or parameterizations based on aerosol activation theory (e.g., Fountoukis and Nenes, 2005; Abdul-Razzak and Ghan, 2002). A systematic analysis of the differences in computed (temperature responses of) aerosol lifetimes between models requires therefore a separate evaluation of effects associated with the hydrological cycle and with aerosol activation.

The proposed analysis is based on Sect. 2 but several processes relevant for water vapor and aerosol, specifically below-cloud evaporation and entrainment, are not explicitly considered. In the first place, the connection between water vapor and aerosol lifetimes in coupled aerosol-climate models will be evaluated. The simulated global and annual water vapor lifetime can be derived from the global water vapor burden and the precipitation flux, and this lifetime can be related to the computed values of $e_{\mathrm{c}}, p_{\mathrm{c}}, c$ and $U$ for all cloud types in the domain, following Eq. (4). For a consistent intermodel comparison of aerosol lifetimes (Eq. 7) an ideal aerosol tracer should be considered that has identical activation and precipitation efficiencies for all models. For example, $e_{\mathrm{a}}$ can be assumed to have a constant value that is the same for all cloud types, while $p_{\mathrm{a}}$ can be assumed equal to $p_{\mathrm{c}}$ for every cloud event. In that case the atmospheric cycling speeds of water vapor and aerosol are related according to a simple lifetime ratio (cf. Eq. 8):

$$
\frac{\tau_{\mathrm{AP}}}{\tau_{\mathrm{v}}}=\frac{\bar{e}_{\mathrm{c}}}{e_{\mathrm{a}}}
$$

with $\bar{e}_{\mathrm{c}}$ an effective or average condensation efficiency derived from

$\bar{e}_{\mathrm{c}}=\frac{\sum_{i} e_{\mathrm{c}, i} p_{\mathrm{c}, i} c_{i} U_{i}}{\sum_{i} p_{\mathrm{c}, i} c_{i} U_{i}}$.

The lifetime ratio describes the relative uptake of water and aerosol in clouds and reflects therefore the aqueous phase concentration of aerosol in cloud water. Intermodel differences in the computed lifetimes and lifetime ratio should be analyzed further to separately assess the significances of differences in cloud physics (condensation, precipitation formation), cloud dynamics (cloud cover, cloud volume), and aerosol transport times in the three-dimensional domain. We note that aerosol in the lower troposphere is more susceptible to wet removal than aerosol in the upper troposphere. Therefore, the simulated aerosol lifetime also depends on the vertical distribution of aerosol (precursors) in the troposphere and thus may reflect the simulated vertical transport efficiency. The simulated water vapor distribution is also influenced by this and depends on, for example, the numerical method used to solve tracer transport and the vertical model resolution (e.g., Roeckner et al., 2006; Rasch et al., 2006; Williamson and Rasch, 1994; Risi et al., 2012). We note that climate models tend to simulate vertical transport too efficiently, so that computed upper tropospheric water vapor burdens are often larger than observed (Lindzen et al., 1996; John and Soden, 2007).

Subsequently, simulations of different climates should be compared for information about changes in water vapor and aerosol lifetimes and shifting contributions from different cloud types. Considering again a constant $e_{\mathrm{a}}$ and equal $p_{\mathrm{c}}$ and $p_{\mathrm{a}}$, the temperature sensitivity of the aerosol-water vapor lifetime ratio is given by

$\frac{\mathrm{d} \ln \left(\tau_{\mathrm{AP}} / \tau_{\mathrm{v}}\right)}{\mathrm{d} \Delta T}=\frac{\mathrm{d} \ln \bar{e}_{\mathrm{c}}}{\mathrm{d} \Delta T}-\frac{\mathrm{d} \ln e_{\mathrm{a}}}{\mathrm{d} \Delta T}$.

According to Eq. (16), a change in lifetime ratio between colder and warmer climates thus suggests a change in the averaged $e_{\mathrm{c}}$, caused by, for example, a change in the contribution from each cloud type to the total removal of water vapor and aerosol as a result of changes in cloud and precipitation distributions and changing transport patterns in the three-dimensional model atmosphere.

Finally, the impact of the aerosol activation efficiency $e_{\mathrm{a}}$ on the aerosol lifetime must be evaluated. Intermodel differences in $e_{\mathrm{a}}$ and how it changes between different climates will contribute to intermodel variabilities in aerosol lifetime and therefore radiative forcing. Similar model experiments as described above but with application of the parameterizations implemented in the models for aerosol activation can be used to analyze and compare the influence of $e_{\mathrm{a}}$.

\section{Summary and discussion}

Changing the surface temperature in climate models leads to changes in the computed atmospheric water vapor burden and lifetime, in evaporation and precipitation, and in the spatial and temporal distribution of clouds and precipitation. The radiative effects of these changes are expressed in the simulated climate sensitivity and vary considerably between models. Changes in cloud and precipitation characteristics, however, also affect the wet deposition efficiency for aerosol and thus the aerosol atmospheric lifetime and burden. This implies that climate change induces an aerosol radiative forcing, even when aerosol emissions and aerosol physical and chemical properties (size distribution and hygroscopicity) remain the same, which is relevant also for natural aerosol. With a few fundamental equations based on Pruppacher and Jaenicke (1995), adequate for steady-state conditions and a well-mixed atmosphere, we explored the connection between atmospheric lifetimes of aerosol and water vapor. The system is constrained to soluble aerosol with wet deposition as only removal mechanism, which is to some extent representative of atmospheric sulfate. Insoluble aerosol such as dust is not considered, nor many processes that are 
relevant for the aerosol lifetime, such as secondary aerosol production and compensating effects between aerosol activation scavenging, below-cloud scavenging and dry deposition. We also neglected any size-dependence of aerosol-cloud interactions, the influence of aerosol scavenging on precipitation formation (the second indirect or "lifetime" effect) and other climate-chemistry feedbacks (Raes et al., 2010).

The equations show that water vapor removal is governed by the processing efficiency of air in clouds, expressed in terms of cloud cover, updraft speed, condensation efficiency and the transfer of cloud water to precipitation. Simulated temperature sensitivities for the water vapor concentration and precipitation following a LW forcing (Held and Soden, 2006) suggest a temperature response of the water vapor lifetime (WLTR) of $+5.3 \pm 2.0 \% \mathrm{~K}^{-1}$. The actual response may be smaller and the uncertainty larger because simulated precipitation temperature sensitivities for SW and LW forcings are different. We note that a recent estimate of the precipitation temperature sensitivity based on ocean salinity is much larger than models predict, i.e., $8 \% \mathrm{~K}^{-1}$ (Durack et al., 2012), which implies a much smaller temperature response of the water vapor lifetime of almost zero (Eq. 9).

Aerosol removal also depends on cloud cover and updraft speed, and on the activation efficiency and the transfer of aerosol from cloud water to precipitation. If temperatureinduced changes in the efficiencies of condensation, aerosol activation, and cloud-precipitation transfer are insignificant, the temperature response of the aerosol lifetime (ALTR) is the same as the WLTR, i.e., $+5.3 \pm 2.0 \% \mathrm{~K}^{-1}$. For the observed global temperature increase of $0.76^{\circ} \mathrm{C}$ between the pre-industrial era and the present day (Solomon et al., 2007) this ALTR suggests an increase of the lifetime of natural aerosol between 2.5 and $5.5 \%$ (Eq. 13). Although it is difficult to relate this directly to a radiative forcing, a first estimate of the order of magnitude can be obtained by assuming a linear relation between aerosol lifetime (or burden) and aerosol direct radiative forcing. Taking as a reference a value of $4 \mathrm{~W} \mathrm{~m}^{-2}$ as the total $\mathrm{SW}$ radiative forcing by natural and anthropogenic aerosol (top-of-atmosphere, clear-sky model estimate from Zhang et al., 2012), the ALTR by itself represents a forcing of the order of $0.1-0.2 \mathrm{~W} \mathrm{~m}^{-2}$. Although this will be smaller for natural aerosol alone, it is of the same order of magnitude as the intermodel standard deviation of computed direct radiative forcing from anthropogenic sulfate in AeroCom, i.e., $0.11 \mathrm{~W} \mathrm{~m}^{-2}$ (Myhre et al., 2013), derived from simulations with pre-industrial and present-day emission scenarios within the same climate. About a third of this is attributed to host-model uncertainties (Stier et al., 2013). We conclude that the dependence of the computed ALTR on simulated properties of the hydrological cycle may be perceived as another host-model uncertainty, and it can be expected that intermodel variability in ALTR contributes to the present range of uncertainty in anthropogenic aerosol radiative forcing.
The derived ALTR is consistent with a global model simulation that applies ideal soluble aerosol-like tracers (Fang et al., 2011), but not with models that employ more realistic aerosol representations and that simulate a wide range of negative to positive values for ALTR. We conclude that the influence of the ALTR on aerosol forcing may be significant, but it is probably small compared to other influences. Particularly important in this respect are changing spatial distributions of aerosol (precursor) emissions and transport routes (Bellouin et al., 2011; Zhang et al., 2007; Carslaw et al., 2010; Zhou et al., 2011), and changes in the aerosol activation efficiency. We present suggestions for model experiments involving idealized aerosol-like tracers that may help to quantify the separate influences on aerosol lifetime and assess their relevance for aerosol-climate simulations.

We finally note that the temperature sensitivity of cloud and precipitation characteristics not only affects aerosol removal and aerosol radiative forcing, but also induces a radiative forcing directly, i.e., the cloud radiative feedback (CRF) (Randall et al., 2007; Dessler and Sherwood, 2009), which appears to be the most important cause of the intermodel variability in climate sensitivity (Dufresne and Bony, 2008; Andrews et al., 2012). The solar wavelengths especially contribute to CRF (Schwartz, 2008), suggesting a strong radiative feedback from clouds in the lower part of the troposphere where also most aerosol resides. A possible correlation between the ALTR and CRF could partly explain the correlation between climate sensitivity and aerosol forcing found in aerosol-climate models (Kiehl, 2007). In the relatively small model comparison in Table 1 such a relation is not apparent, but a dedicated model intercomparison study, as outlined in Sect. 3.2 and including an analysis of cloud radiative effects, may provide more information on this.

Acknowledgements. We thank the anonymous reviewers: their critical reading and their comments and suggestions helped to improve the manuscript substantially.

Edited by: J. Quaas

\section{References}

Abdul-Razzak, H. and Ghan, S. J.: A parameterization of aerosol activation, 3, Sectional representation, J. Geophys. Res., 107, 4026, doi:10.1029/2001JD000483, 2002.

Albrecht, B. A.: Aerosols, cloud microphysics and fractional cloudiness, Science, 245, 1227-1230, 1989.

Allen, M. R. and Ingram, W. J.: Constraints on future changes in climate and the hydrologic cycle, Nature, 419, 224-232, 2002.

Andreae, M. O., Jones, C. D., and Cox, P. M.: Strong presentday cooling implies a hot future, Nature, 435, 1187-1190, doi:10.1038/nature03671, 2005.

Andrews, T. and Forster, P. M.: The transient response of globalmean precipitation to increasing carbon dioxide levels, Environ. Res. Lett., 5, 025212, doi:10.1088/1748-9326/5/2/025212, 2010. 
Andrews, T., Gregory J. M., Webb, M. J., and Taylor, K. E.: Forcing, feedbacks and climate sensitivity in CMIP5 coupled atmosphere-ocean climate models, Geophys. Res. Lett., 39, L09712, doi:10.1029/2012GL051607, 2012.

Bala, G., Duffy, P. B., and Taylor, K. E.: Impact of geoengineering schemes on the global hydrological cycle, P. Natl. Acad. Sci., 105, 7664-7669, doi:10.1073/pnas.0711648105, 2008.

Bala, G., Caldeira, K., and Nemani, R.: Fast versus Slow Response in Climate Change: Implications for the Global Hydrological Cycle, Climate Dynam., 35, 423-434, doi:10.1007/s00382-0090583-y, 2009.

Bellouin, N., Rae, J. G. L., Jones, A., Johnson, C. E., Haywood, J. M., and Boucher, O.: Aerosol forcing in the Climate Model Intercomparison Project (CMIP5) simulations by HadGEM2-ES and the role of ammonium nitrate, J. Geophys. Res., 116, D20206, doi:10.1029/2011JD016074, 2011.

Bony, S., Colman, R., Kattsov, V. M, Allan, R. P., Bretherton, C. S., Dufresne, J.-L., Hall, A., Hallegatte, S., Holland, M. M., Ingram, W., Randall, D. A., Soden, B. J., Tselioudis, G., and Webb, M. J.: How well do we understand and evaluate climate change feedback processes?, J. Climate, 19, 3445-3482, doi:10.1175/JCLI3819.1, 3445-3482, 2006.

Carslaw, K. S., Boucher, O., Spracklen, D. V., Mann, G. W., Rae, J. G. L., Woodward, S., and Kulmala, M.: A review of natural aerosol interactions and feedbacks within the Earth system, Atmos. Chem. Phys., 10, 1701-1737, doi:10.5194/acp-10-17012010, 2010.

Charlson, R. J., Schwartz, S. E., Hales, J. M., Cess, R. D., Coakley Jr., J. A., Hansen, J. E., and Hofmann, D. J. Climate forcing by anthropogenic aerosols, Science, 255, 423-430, 1992.

Croft, B., Lohmann, U., Martin, R. V., Stier, P., Wurzler, S., Feichter, J., Hoose, C., Heikkilä, U., van Donkelaar, A., and Ferrachat, S.: Influences of in-cloud aerosol scavenging parameterizations on aerosol concentrations and wet deposition in ECHAM5-HAM, Atmos. Chem. Phys., 10, 1511-1543, doi:10.5194/acp-10-1511-2010, 2010.

Dentener, F., Kinne, S., Bond, T., Boucher, O., Cofala, J., Generoso, S., Ginoux, P., Gong, S., Hoelzemann, J. J., Ito, A., Marelli, L., Penner, J. E., Putaud, J.-P., Textor, C., Schulz, M., van der Werf, G. R., and Wilson, J.: Emissions of primary aerosol and precursor gases in the years 2000 and 1750 prescribed data-sets for AeroCom, Atmos. Chem. Phys., 6, 4321-4344, doi:10.5194/acp-64321-2006, 2006.

Dessler, A. E. and Sherwood, S. C.: A matter of humidity, Science, 323, 1020-1021, doi:10.1126/science.1171264, 2009.

Donahue, N. M., Epstein, S. A., Pandis, S. N., and Robinson, A. L.: A two-dimensional volatility basis set: 1. organic-aerosol mixing thermodynamics, Atmos. Chem. Phys., 11, 3303-3318, doi:10.5194/acp-11-3303-2011, 2011.

Dufresne, J. L. and Bony, S.: An Assessment of the primary sources of spread of global warming estimates from coupled atmosphere-ocean models, J. Climate, 21, 5135-5144, doi:10.1175/2008JCLI2239.1, 2008.

Durack, P. J., Wijffels, S. E., and Matear, R. J.: Ocean salinities reveal strong global water cycle intensification during 1950 to 2000 , Science, 336, 455-458, doi:10.1126/science.1212222, 2012.

Dusek, U, Frank, G. P., Hildebrandt, L., Curtius, J., Schneider, J., Walter, S., Chand, D., Drewnick, F., Hings, S., Jung, D., Bor- rmann, S., and Andreae, M. O.: Size matters more than chemistry for cloud-nucleating ability of aerosol particles, Science, 312, 1375-1378, doi:10.1126/science.1125261, 2006.

Fang, Y., Fiore, A. M., Horowitz, L. W., Gnanadesikan, A., Held, I., Chen, G., Vecchi, G., and Levy, H.: The impacts of changing transport and precipitation on pollutant distributions in a future climate, J. Geophys. Res., 116, D18303, doi:10.1029/2011JD015642, 2011.

Forster, P., Ramaswamy, V., Artaxo, P., Berntsen, T., Betts, R., Fahey, D. W., Haywood, J., Lean, J., Lowe, D. C., Myhre, G., Nganga, J., Prinn, R., Raga, G., Schulz, M., and van Dorland, R.: Changes in Atmospheric Constituents and in Radiative Forcing, in: Climate Change 2007: The Physical Science Basis. Contribution of WG I to the Fourth Assessment Report of the Intergovernmental Panel on Climate Change, edited by: Solomon, S., Qin, D., Manning, M., Chen, Z., Marquis, M., Averyt, K. B., Tignor, M., and Miller, H. L., Cambridge University Press, Cambridge, United Kingdom and New York, NY, USA, 2007.

Held, I. M. and Soden, B. J.: Robust responses of the hydrological cycle to global warming, J. Climate, 19, 5686-5699, 2006.

Jacobson, M. C., Hansson, H. C., Noone, K. J., and Charlson, R. J.: Organic atmospheric aerosols: Review and state of the science, Rev. Geophys., 38, 267-294, 2000.

Jensen, J. B. and Charlson, R. J.: On the efficiency of nucleation scavenging, Tellus, B, 36, 367-375, 1984.

Jimenez, J. L., Canagaratna, M. R., Donahue, N. M., et al.: Evolution of organic aerosols in the atmosphere, Science, 326, 15251529, doi:20.1126/science.1180353, 2009.

John, V. O. and Soden, B. J.: Temperature and humidity biases in global climate models and their impacts on climate feedbacks, Geophys. Res. Lett., 34, L18605, doi:10.1029/2007GL030736, 2007.

Kerr, R. A.: Another global warming icon comes under attack, Science, 317, 28-29, doi:10.1126/science.317.5834.28a, 2007.

Kiehl, J. T.: Twentieth century climate model response and climate sensitivity, Geophys. Res. Lett., 34, L22710, doi:10.1029/2007GL031383, 2007.

Kloster, S., Dentener, F., Feichter, J., Raes, F., Roeckner, E., Lohmann, U., and Fischer-Bruns, I.: A GCM study of future climate response to air pollution reduction, Climate Dynam., 34, 1177-1194, doi:10.1007/s00382-009-0537-0, 2010.

Knutti, R. and Hegerl, G. C.: The equilibrium sensitivity of the Earth's temperature to radiation changes, Nat. Geosci., 236-243, 2008.

Lambert, F. H. and Faull, N. E.: Tropospheric adjustment: The response of two general circulation models to a change in insolation, Geophys. Res. Lett., 34, L03701, doi:10.1029/2006GL028124, 2007.

Liao, H., Chen, W.-T., and Seinfeld, J. H.: Role of climate change in global predictions of future tropospheric ozone, and aerosols, J. Geophys. Res., 111, D12304, doi:10.1029/2005JD006852, 2006.

Lindzen, R. S.: The importance and nature of the water vapor budget in nature and models, Climate Sensitivity to Radiative Perturbations: Physical Mechanisms and Their Validation, edited by: Le Treut, H., NATO ASI Series, Vol. IX, Springer-Verlag, 51-66, 1996.

Lohmann, U. and Feichter, J.: Global indirect aerosol effects: a review, Atmos. Chem. Phys., 5, 715-737, doi:10.5194/acp-5-715$2005,2005$. 
Lohmann, U., Rotstayn, L., Storelvmo, T., Jones, A., Menon, S., Quaas, J., Ekman, A. M. L., Koch, D., and Ruedy, R.: Total aerosol effect: radiative forcing or radiative flux perturbation?, Atmos. Chem. Phys., 10, 3235-3246, doi:10.5194/acp-10-32352010, 2010.

Myhre, G., Samset, B. H., Schulz, M., Balkanski, Y., Bauer, S., Berntsen, T. K., Bian, H., Bellouin, N., Chin, M., Diehl, T., Easter, R. C., Feichter, J., Ghan, S. J., Hauglustaine, D., Iversen, T., Kinne, S., Kirkevåg, A., Lamarque, J.-F., Lin, G., Liu, X., Lund, M. T., Luo, G., Ma, X., van Noije, T., Penner, J. E., Rasch, P. J., Ruiz, A., Seland, Ø., Skeie, R. B., Stier, P., Takemura, T., Tsigaridis, K., Wang, P., Wang, Z., Xu, L., Yu, H., Yu, F., Yoon, J.-H., Zhang, K., Zhang, H., and Zhou, C.: Radiative forcing of the direct aerosol effect from AeroCom Phase II simulations, Atmos. Chem. Phys., 13, 1853-1877, doi:10.5194/acp-13-18532013, 2013.

Pruppacher, H. R. and Jaenicke, R.: The processing of water vapor and aerosols by atmospheric clouds, a global estimate, Atmos. Res., 38, 283-295, 1995.

Racherla, P. N. and Adams, P. J.: Sensitivity of global tropospheric ozone and fine particulate matter concentrations to climate change, J. Geophys. Res., 111, D24103, doi:10.1029/2005JD006939, 2006.

Raes, F., Liao, H., Chen, W.-T., and Seinfeld, J. H.: Atmospheric chemistry-climate feedbacks, J. Geophys. Res., 115, D12121, doi:10.1029/2009JD013300, 2010.

Randall, D. A., Wood, R. A., Bony, S., Colman R., Fichefet, T., Fyfe, J., Kattsov, V., Pitman, A., Shukla, J., Srinivasan, J., Stouffer, R. J., Sumi, A., and Taylor, K. E.: Climate Models and Their Evaluation, in: Climate Change 2007: The Physical Science Basis. Contribution of Working Group I to the Fourth Assessment Report of the Intergovernmental Panel on Climate Change, edited by: Solomon, S., Qin, D., Manning, M., Chen, Z., Marquis, M., Averyt, K. B., Tignor, M., and Miller, H. L., Cambridge University Press, Cambridge, United Kingdom and New York, NY, USA, 2007.

Rasch, P. J., Coleman, D. B., Mahowald, N., Williamson, D. L., Lin, S. J., Boville, B. A., and Hess, P.: Characteristics of atmospheric transport using three numerical formulations for atmospheric dynamics in a single GCM framework, J. Climate, 19, 2243-2266, doi:10.1175/JCLI3763.1, 2006.

Risi, C., Noone, D. C., Worden, J., Frankenberg, C., Stiller, G. P., Kiefer, M., Funke, B., Walker, K. A., Bernath, P. F., Schneider, M., Bony, S., Lee, J., Brown, D. P., and Sturm, C.: Processevaluation of tropospheric humidity simulated by general circulation models using water vapor isotopic observations: 2 . Using isotopic diagnostics to understand the mid and upper tropospheric moist bias in the tropics and subtropics, J. Geophys. Res., 117, D05304, doi:10.1029/2011JD016623, 2012.

Roeckner, E., Brokopf, R., Esh, M., Giorgetta, M., Hagemann, S., Kornblueh, L., Manzini, E., Schlese, U., and Schulzweida, U.: Sensitivity of Simulated Climate to Horizontal and Vertical Resolution in the ECHAM5 Atmosphere Model, J. Climate, 19, 3771-3791, doi:10.1175/JCLI3824.1, 2006.

Roelofs, G. J., Lelieveld, J., and Ganzeveld, L.: Simulation of global sulfate distribution and the influence on effective cloud drop radii with a coupled photochemistry sulfur cycle model. Tellus B, 50, 224-242, doi:10.1034/j.1600-0889.1998.t01-2-00002.x, 1998.
Roelofs, G. J., Kasibhatla, P., Barrie, L., Bergmann, D., Bridgeman, C., Chin, M., Christensen, J., Easter, R., Feichter, J., Jeuken, A., Kjellstrom, E., Kock, D., Land, C., Lohmann, U., and Rasch, P.: Analysis of regional budgets of sulphur species modeled for the COSAM exercise, Tellus, B, 53, 673-694, 2001.

Rosenfeld, D., Lohmann, U., Raga, G. B., O’Dowd, C., Kulmala, M., Fuzzi, S., Reissell, A., and Andreae, M. O .: Flood or drought: how do aerosols affect precipitation?, Science, 321, 1309-1313, doi:10.1126/science.1160606, 2008.

Schwartz, S. E.: Uncertainty in Climate Sensitivity: Causes, Consequences, Challenges, Energy Environ. Sci., 1, 430-453, doi:10.1039/b810350j, 2008.

Shindell, D. T., Chin, M., Dentener, F., Doherty, R. M., Faluvegi, G., Fiore, A. M., Hess, P., Koch, D. M., MacKenzie, I. A., Sanderson, M. G., Schultz, M. G., Schulz, M., Stevenson, D. S., Teich, H., Textor, C., Wild, O., Bergmann, D. J., Bey, I., Bian, H., Cuvelier, C., Duncan, B. N., Folberth, G., Horowitz, L. W., Jonson, J., Kaminski, J. W., Marmer, E., Park, R., Pringle, K. J., Schroeder, S., Szopa, S., Takemura, T., Zeng, G., Keating, T. J., and Zuber, A.: A multi-model assessment of pollution transport to the Arctic, Atmos. Chem. Phys., 8, 5353-5372, doi:10.5194/acp-85353-2008, 2008.

Solomon, S., Qin, D., Manning, M., Alley, R. B., Berntsen, T., Bindoff, N. L., Chen, Z., Chidthaisong, A., Gregory, J. M., Hegerl, G. C., Heimann, M., Hewitson, B., Hoskins, B. J., Joos, F., Jouzel, J., Kattsov, V., Lohmann, U., Matsuno, T., Molina, M., Nicholls, N., Overpeck, J., Raga, G., Ramaswamy, V., Ren, J., Rusticucci, M., Somerville, R., Stocker, T. F., Stouffer, R. J., Whetton, P., Wood, R. A., and Wratt, D.: Technical Summary, in: Climate Change 2007: The Physical Science Basis, Contribution of Working Group I to the Fourth Assessment Report of the Intergovernmental Panel on Climate Change, edited by: Solomon, S., Qin, D., Manning, M., Chen, Z., Marquis, M., Averyt, K. B., Tignor, M., and Miller, H. L., Cambridge University Press, Cambridge, United Kingdom and New York, NY, USA, 19-91, 2007.

Stier, P., Feichter, J., Kinne, S., Kloster, S., Vignati, E., Wilson, J., Ganzeveld, L., Tegen, I., Werner, M., Balkanski, Y., Schulz, M., Boucher, O., Minikin, A., and Petzold, A.: The aerosol-climate model ECHAM5-HAM, Atmos. Chem. Phys., 5, 1125-1156, doi:10.5194/acp-5-1125-2005, 2005.

Stier, P., Feichter, J., Roeckner, E., Kloster, S., and Esch, M.: The evolution of the global aerosol system in a transient climate simulation from 1860 to 2100, Atmos. Chem. Phys., 6, 3059-3076, doi:10.5194/acp-6-3059-2006, 2006.

Stier, P., Schutgens, N. A. J., Bellouin, N., Bian, H., Boucher, O., Chin, M., Ghan, S., Huneeus, N., Kinne, S., Lin, G., Ma, X., Myhre, G., Penner, J. E., Randles, C. A., Samset, B., Schulz, M., Takemura, T., Yu, F., Yu, H., and Zhou, C.: Host model uncertainties in aerosol radiative forcing estimates: results from the AeroCom Prescribed intercomparison study, Atmos. Chem. Phys., 13, 3245-3270, doi:10.5194/acp-13-3245-2013, 2013.

Textor, C., Schulz, M., Guibert, S., Kinne, S., Balkanski, Y., Bauer, S., Berntsen, T., Berglen, T., Boucher, O., Chin, M., Dentener, F., Diehl, T., Easter, R., Feichter, H., Fillmore, D., Ghan, S., Ginoux, P., Gong, S., Grini, A., Hendricks, J., Horowitz, L., Huang, P., Isaksen, I., Iversen, I., Kloster, S., Koch, D., Kirkevåg, A., Kristjansson, J. E., Krol, M., Lauer, A., Lamarque, J. F., Liu, X., Montanaro, V., Myhre, G., Penner, J., Pitari, G., Reddy, S., Seland, Ø., Stier, P., Takemura, T., and Tie, X.: Analysis and quantifica- 
tion of the diversities of aerosol life cycles within AeroCom, Atmos. Chem. Phys., 6, 1777-1813, doi:10.5194/acp-6-1777-2006, 2006.

Topping, D. O. and McFiggans, G.: Tight coupling of particle size, number and composition in atmospheric cloud droplet activation, Atmos. Chem. Phys., 12, 3253-3260, doi:10.5194/acp-12-32532012, 2012.

Twomey, S.: Pollution and the planetary albedo, Atmos. Environ., 8, 1251-1256, 1974.

Webb, M. J., Lambert, F. H., and Gregory, J. M.: Origins of differences in climate sensitivity, forcing and feedback in climate models, Clim. Dynam., 40, 677-707, doi:10.1007/s00382-0121336-x, 2013.

Williamson, D. L. and Rasch, P. J.: Water vapor transport in the NCAR CCM2, Tellus A, 46, 34-51, 1994.
Zhang, X., Zwiers, Z. W., Hegerl, G. C., Lambert, F. H., Gillett, N. P., Solomon, S., Stott, P. A., and Nozawa, T.: Detection of human influence on twentieth-century precipitation trends, Nature, 448, 461-466, 2007.

Zhang, K., O’Donnell, D., Kazil, J., Stier, P., Kinne, S., Lohmann, U., Ferrachat, S., Croft, B., Quaas, J., Wan, H., Rast, S., and Feichter, J.: The global aerosol-climate model ECHAM-HAM, version 2: sensitivity to improvements in process representations, Atmos. Chem. Phys., 12, 8911-8949, doi:10.5194/acp-12-89112012, 2012.

Zhou, Y. P., Xu, K.-M., Sud, Y. C., and Betts, A. K.: Recent trends of the tropical hydrological cycle inferred from Global Precipitation Climatology Project and International Satellite Cloud Climatology Project data, J. Geophys. Res., 116, D09101, doi:10.1029/2010JD015197, 2011. 